\title{
線路直下地下切替工法（STRUM）による鉄道営業線 の地下化工事（東急東横線渋谷駅～代官山駅）
}

高田 久夫*1 - 鈴木 隆文*2 2 丸山 明紀*3

\section{1.はじめに}

現在，東京圈では鉄道ネットワークの拡充に向けて， 既存インフラを有効活用した事業が進められている。

本事業は，東急東横線の渋谷駅から代官山駅までの約 $1.4 \mathrm{~km}$ の区間を地下化し，平成 20 年 6 月に開業した都 市高速鉄道 13 号線（以下「東京メト口副都心線」とい う）と渋谷駅にて相互直通運転を行うものである（図-1)。

この事業により, 平成 25 年 3 月 16 日に相互直通運転 を開始し，東武東上線・西武池袋線から東京メ卜口有楽

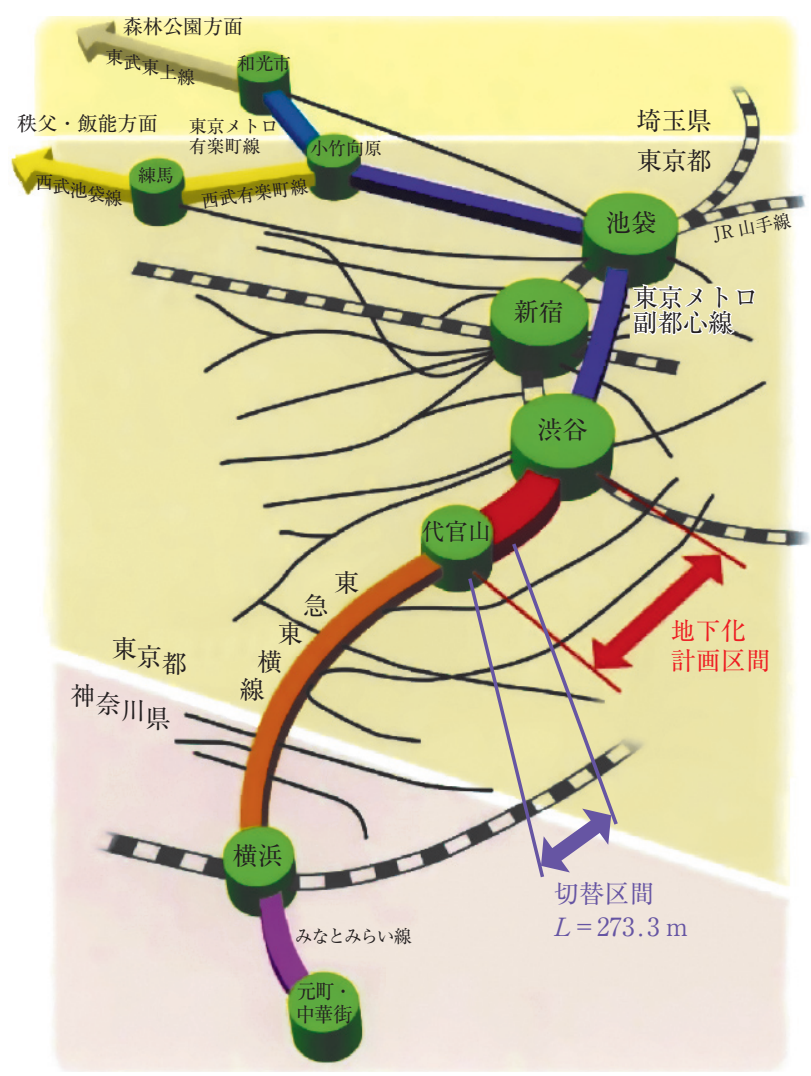

図-1＼cjkstart全体事業概要図

＊1 たかだ・ひさお／東京急行電鉄株）鉄道事業本部 工務部 工事事 務所 所長

＊2すずき・たかふみ/東京急行電鉄侏 鉄道事業本部 工務部 工事 事務所 課長補佐

＊3 まるやま・あきのり／東急建設侏）首都圈土木支店 代官山作業 所 所長
町線・副都心線を経て，東急東横線および横浜高速鉄道 みなとみらい線までがひとつの路線として結ばれ，東京 圈の広域的な鉄道ネットワークのひとつが形成された。

これによって，都市交通のさらなる利便性向上や円滑 化が図られるとともに，東京の都市再生にも寄与するこ とが期待される。

本稿では，東横線の新設地下線への切替区間である代 官山駅付近において，既存の鉄道施設を供用しながら施 工した地下化工事について報告する。

\section{2. 工 事 概 要}

工事件名：(13 号線相直) 東横線淽谷～代官山間地下 化工事（土木工事第 3 工区）

発 注 者: 東京急行電鉄(秼)

施 工 者：東急建設侏

工事場所：東京都渋谷区代官山町 18 番地他

工 $\quad$ 期：平成 17 年 1 月～平成 27 年 3 月

工事延長 : $L=273.3 \mathrm{~m}$

線路切替工事数量：桁扛上区間 $\quad L=68.0 \mathrm{~m}$

$$
\begin{array}{ll}
\text { クレーン撤去区間 } & L=71.2 \mathrm{~m} \\
\text { 桁降下区間 } & L=76.0 \mathrm{~m} \\
\text { 砂利降下区間 } & L=58.1 \mathrm{~m} \\
\text { 乗降ホーム切替 } & \text { 一式 }
\end{array}
$$

鉄道営業線の線路切替工事は, 線路および停車場など の鉄道施設を供用しながら行うため, 仮線方式で行うの が一般的であるが，住宅や商業ビルなどが密集した市街 地では，仮線用地を確保することが困難な場合がある。

このような状況に対応すべく開発したのが線路直下 地下切替工法 (STRUM : Shifting Track Right Under Method）で，仮線を用いず，既存線路の直下に新設線 路を設置し，一晚で既存線路を撤去・移動して新設線路 に切替える工法である。

本工法は，東急池上線戸越銀座～旗の台駅間連続立体 交差工事，みなとみらい線と東急東横線の相互直通運転 に伴う東横線東白楽～横浜駅間地下化工事，東急目蒲線 不動前駅付近立体交差工事などで実績がある。

当該範囲である代官山駅周辺は, 住宅や商業ビルなど が密集して扔り，仮線用地を確保することが困難であっ 

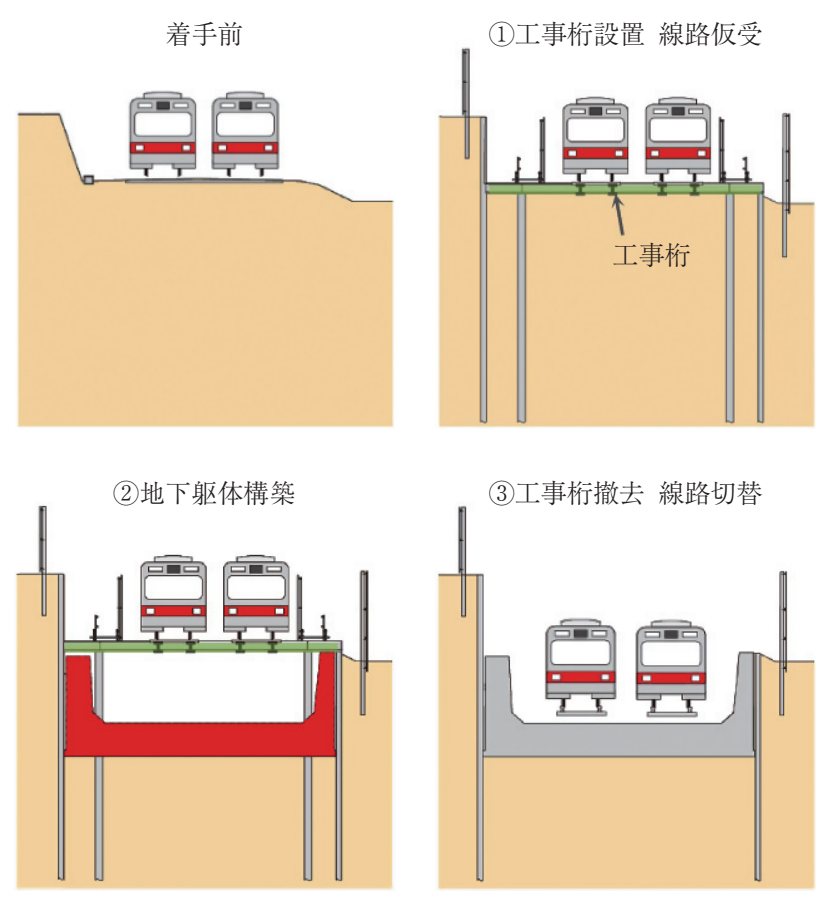

(4)残躯体構築

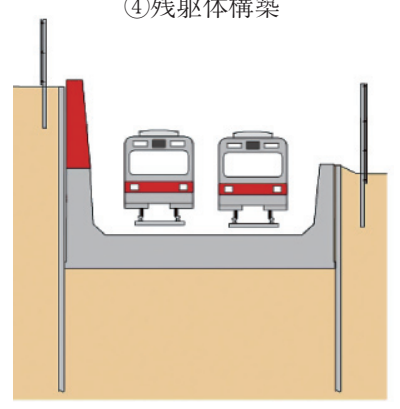

(5)完 成

図-2 線路直下地下切替工法 (STRUM) による 地下化工事の施工手順

たことから，線路直下地下切替工法（STRUM）にて線 路切替を行った。

東横線の運行を止めずに地下化工事を遂行するため, (1)線路を工事桁で仮受，(2)工事桁の下で地下躯体を構築 し線路敷設, (3)工事桁を撤去・移設して地下線路へ切替, (4)残躯体の構築といった手順で施工した（図-2）。

\section{3. 躯体構築工事}

\section{（1） U 型擁壁構築}

線路を仮受している工事桁の下にて鉄筋コンクリート の U 型擁壁を構築した (写真-1)。

(2) ホーム構築

既設ホームを仮ホーム化して供用しながら，仮ホーム の下において地下化後の新設ホームを鉄筋コンクリート で構築した (写真-2)。

(3) 仮ホーム受替

線路切替当夜は, 仮ホームを撤去して新設ホームを供 用するが，重機の使用は困難であった。そのため，人力 で仮ホームの撤去が可能となるよう，事前に仮ホームを 支える鋼材 $(\mathrm{H}-125, \mathrm{H}-150$ 等）を，人力による撤去運

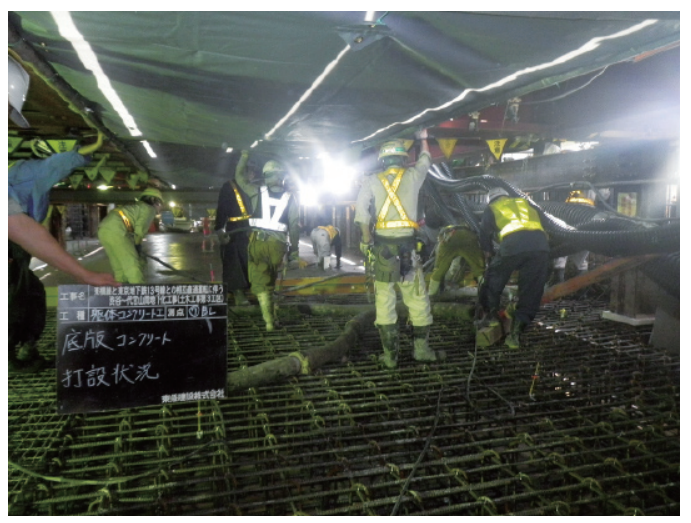

写真-1 U 型擁壁コンクリート打込み状況

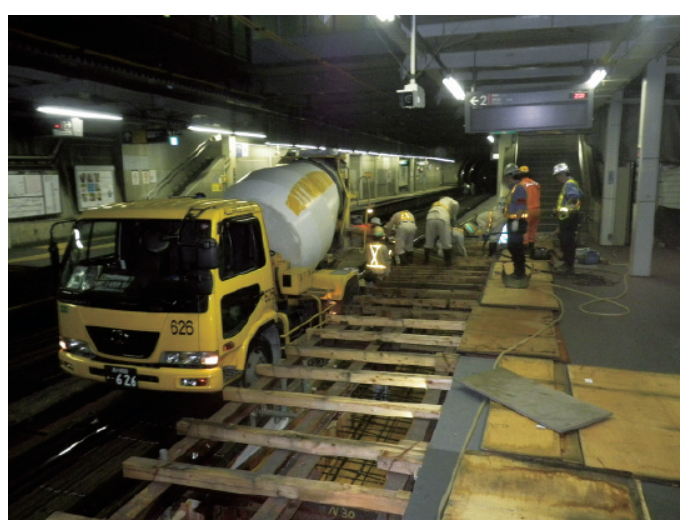

写真-2 ホームコンクリート打込み状況

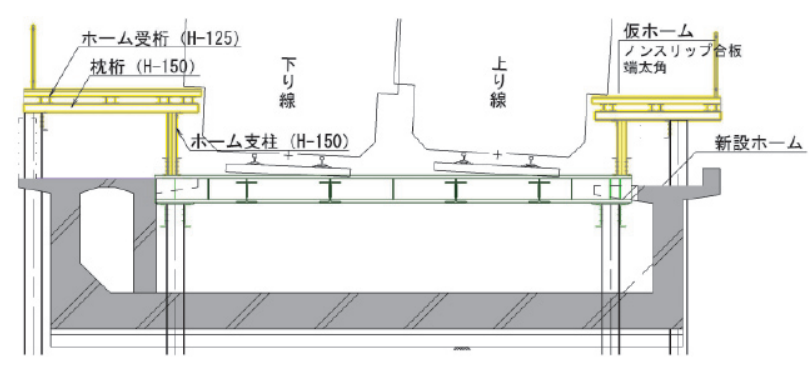

凸

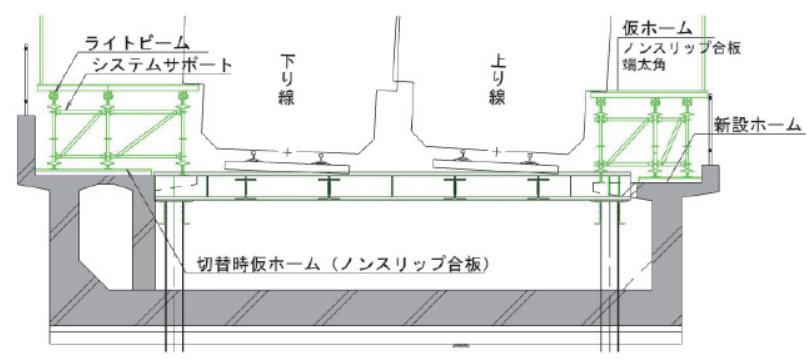

図-3 仮ホーム受替図

搬が容易なシステムサポート等に交換した（図-3）。

\section{4. 線路切替工事}

\section{1 施エブロック割}

施工ブロック割を図-4に示す。切替工事はクレーン による工事桁撤去を基本とするが，大型クレーンを配置 できる側道や作業ヤードが僅かしかないこと, 工事桁下 に空間がなく事前に線路が敷設できない区間があるこ 

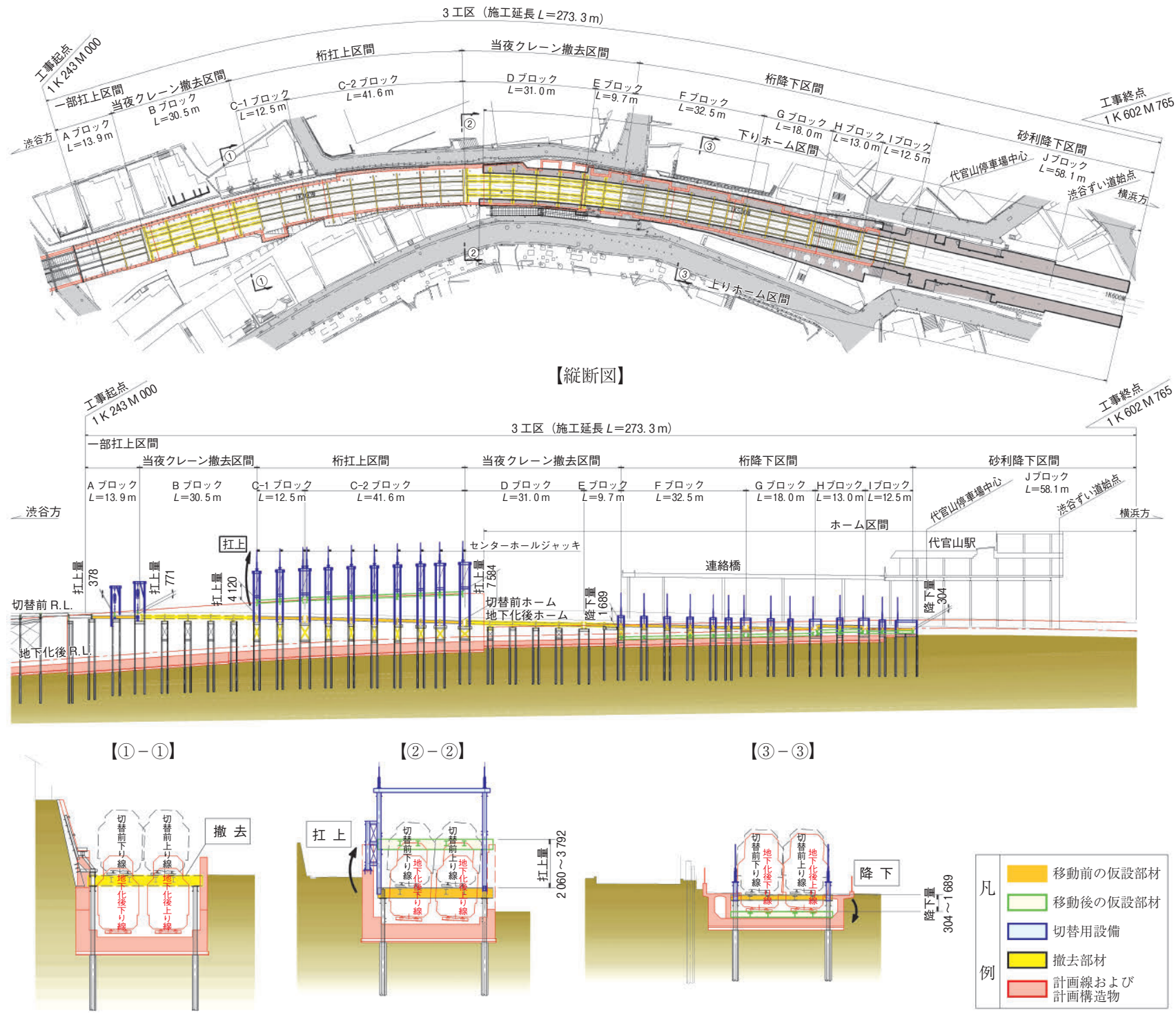

[(3) - (3) 】

図-4＼cjkstart線路切替施エブロック割図

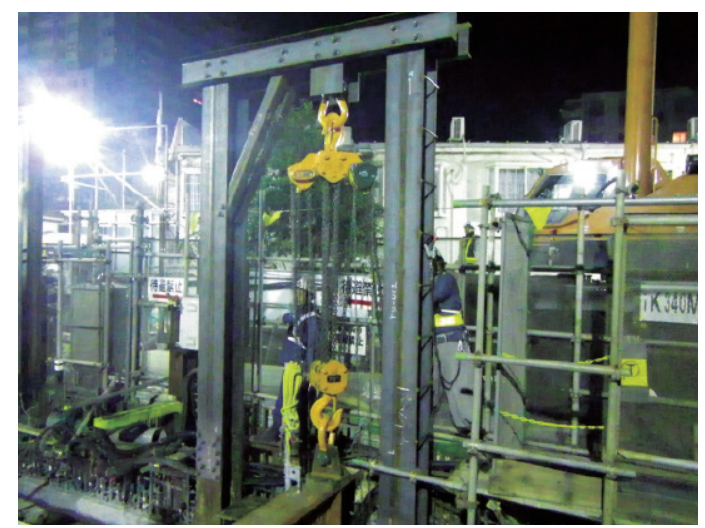

写真-3＼cjkstart手動チェーンブロック（A ブロック）

と，ホーム作業と線路側作業の競合する区間があること など，諸条件とリスクを勘案して「クレーン撤去」「工 事桁扛上」「工事桁降下」「道床砂利降下」の 4 つの工法 を組み合わせて 6 区間，11 ブロックに区分した。
（1）一部扛上区間（A ブロック）

作業ヤードが非常に狭あいで，クレーン配置および工 事桁の仮置きが困難であったことから，簡易な手動 チェーンブロック (20 t 吊)を用いて工事桁の扛上を行っ た (写真-3)。

（2）クレーン撤去区間（B， D， E ブロック）

作業ヤードの確保が可能，あるいは側道が使用できる B， D ， E ブロックは，線路切替当夜にクレーンを用い て工事桁を撤去した。

B ブロックでは，作業ヤードに $100 \mathrm{t}$ 吊， $65 \mathrm{t}$ 吊， $60 \mathrm{t}$ 吊の移動式クレーンを 3 台配置し, 各クレーンで 5 ピー スの工事桁撤去を行った（図-5, 図-6)。

$\mathrm{D}, \mathrm{E}$ ブロックでは，上り線側の側道に 3 台の移動式 クレーン (100 t 吊, $60 \mathrm{t}$ 吊, $50 \mathrm{t}$ 吊), 下り線側の側道 に $35 \mathrm{t}$ 吊の移動式クレーンを 1 台配置し, 各クレーンで 5 〜 ピースの工事桁撤去を行った（図-7, 写真-4）。

（3）桁扛上区間（Cブロック）

クレーン配置および工事桁の仮置きが困難な C ブロッ 


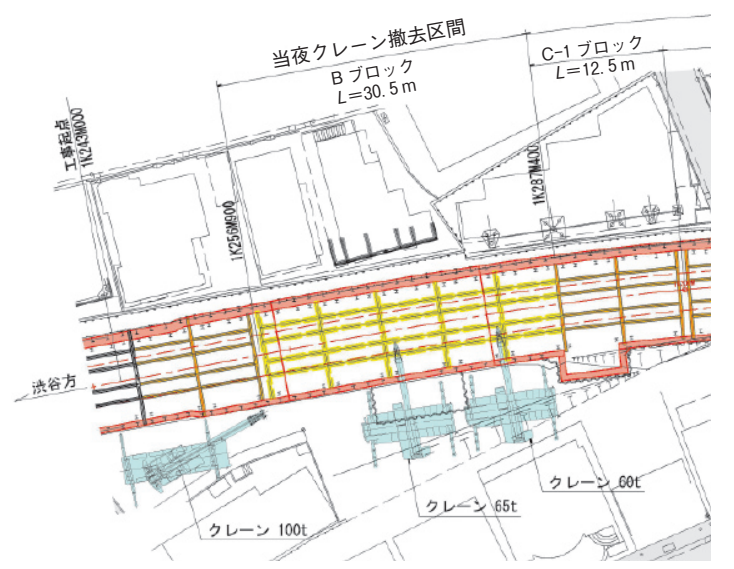

図-5 クレーン配置図（B ブロック）

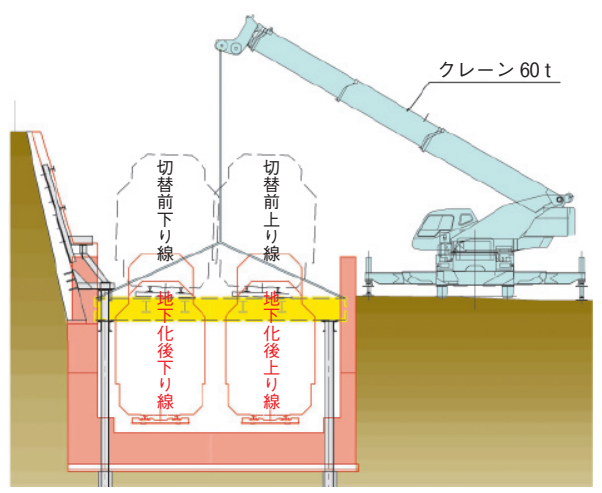

図-6 クレーン撤去状況図（B ブロック）

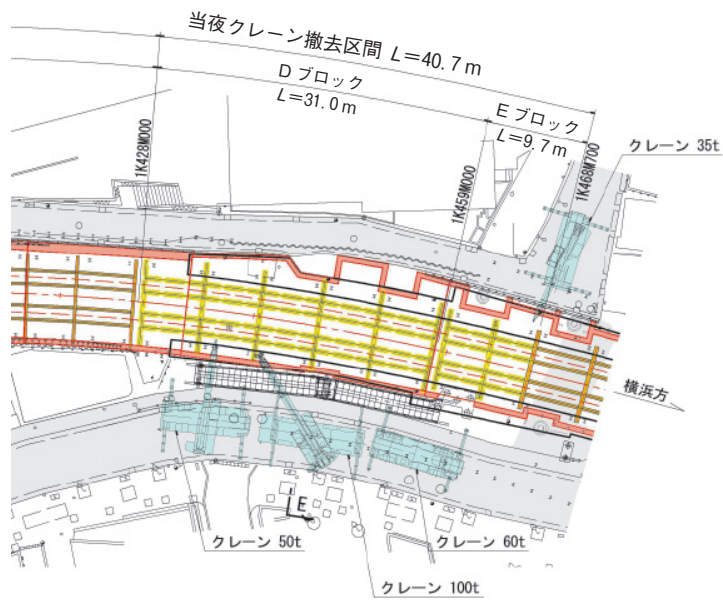

図-7クレーン配置図（D， E ブロック）

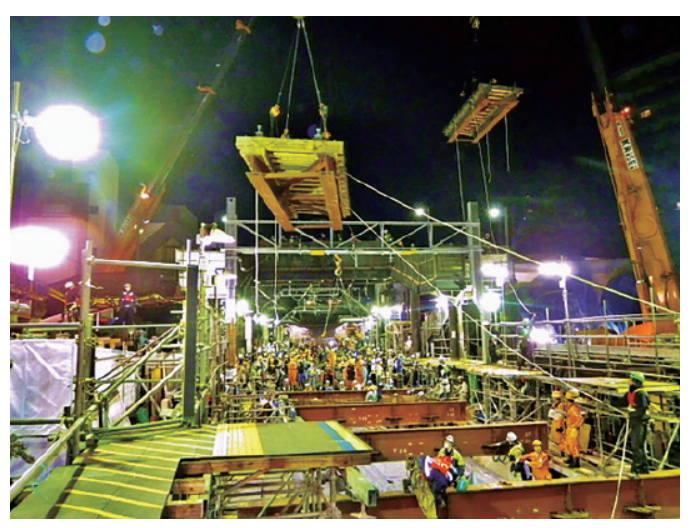

写真-4 桁撤去状況（D， E ブロック） クは，50tセンターホールジャッキをジャッキ架台 (門構) に設置し，工事桁を吊り上げて新設地下線の建築限界に 支障しない高さまで扛上した（図-8，図-9，写真-5)。

（4）桁降下区間（F，G，H，I ブロック）

工事桁下に空間がなく，事前に線路を敷設できない区

【平面図】

桁扛上区間 $L=54.1 \mathrm{~m}$

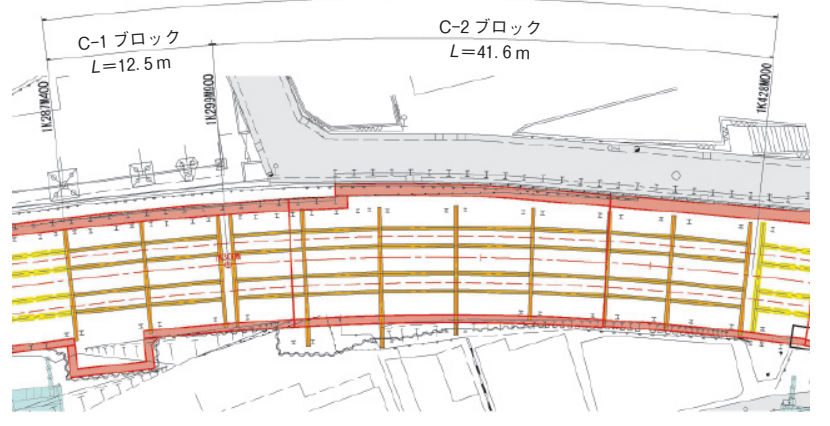

【縦断図】

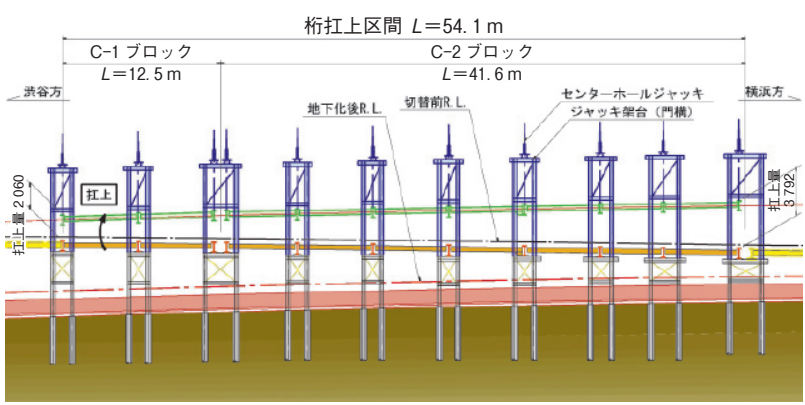

図-8＼cjkstart桁扛上設備配置図（C ブロック）

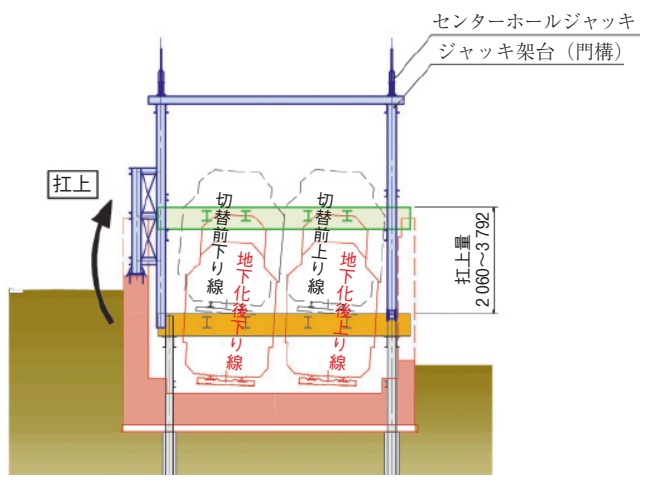

図-9＼cjkstart桁扛上設備図（C ブロック）

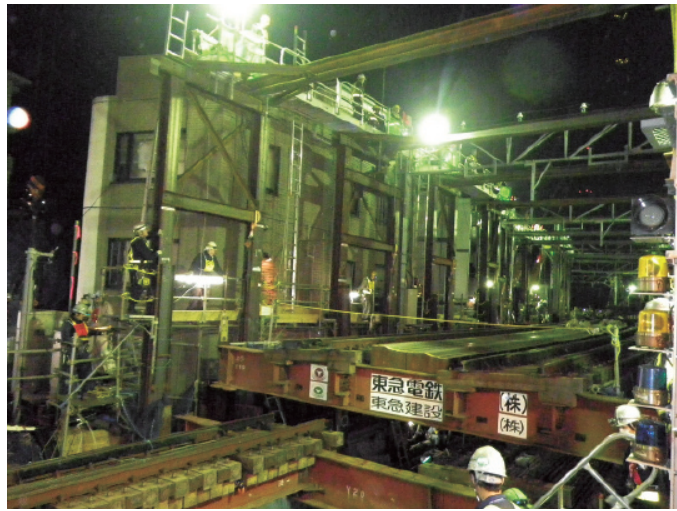

写真-5 林扛上状況（C ブロック） 
間は, 工事桁を降下して切替えた。ホーム幅員が狭く, 背面側の鉄道用地が非常に狭あいであるため，降下設備 は仮ホーム下に設置した。

F, G， H ブロックは，門構を含めた降下設備一式を あらかじめ設置しておき，ゲビンデ棒をジョイントカプ ラに接続する構造とした。そうすることで, 線路切替当 夜はゲビンデ棒を仮ホーム上から挿入するだけで降下設 備の準備ができるようにした（図-10，写真-6）。

Iブロックは降下量が小さいため, 円筒型油圧ジャッ キをホーム下に設置して 2 台のジャッキを交互に使用す ることで工事桁を降下した。そうすることで，降下設備 が新設ホームに支障しないため, 残工事を減少させるこ とができた。

（5）砂利降下区間（J ブロック）

既設線と新設地下線を擦り付ける降下量の小さい区間 は，軌道工事にて降下を行った。
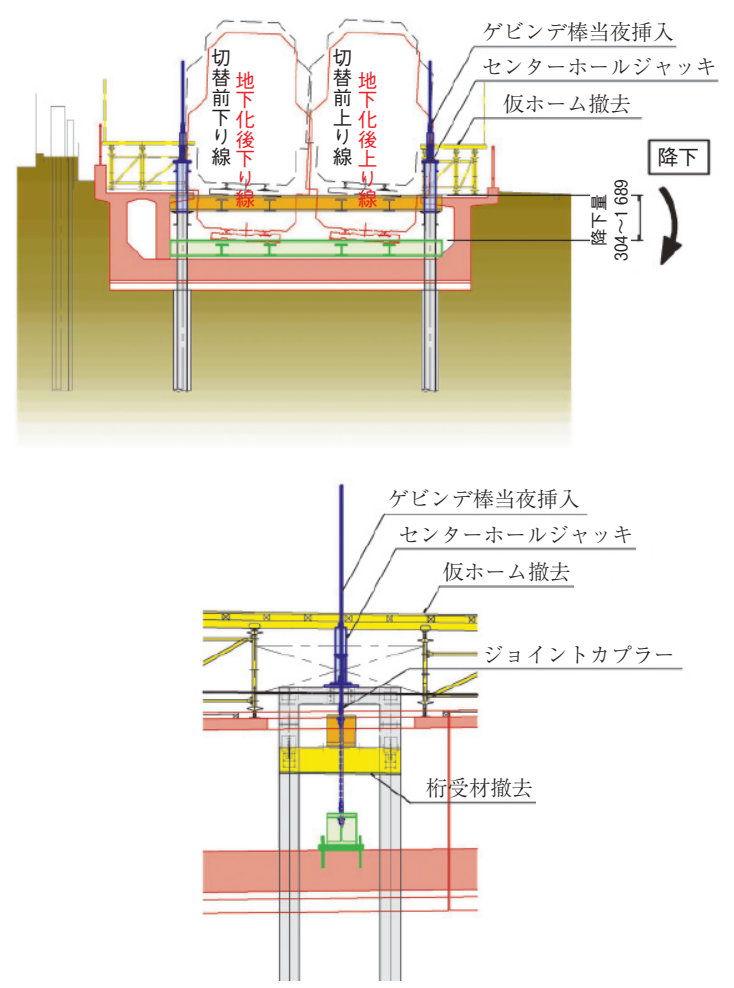

図-10＼cjkstart桁降下設備図（Fブロック）

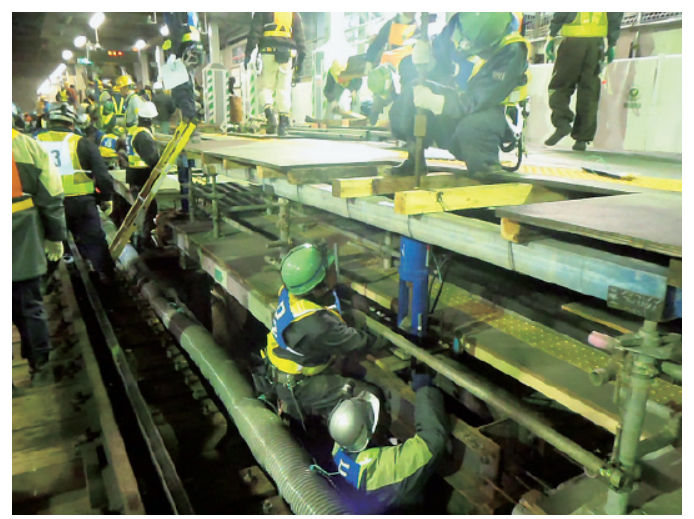

写真-6 桁降下設備準備状況（G ブロック付近）

\section{2 リスク管理}

今回の線路切替工事は, 直後より他社線（東京メトロ, 東武鉄道，西武鉄道，横浜高速鉄道）との相互直通運転 が開始されることから，終初電間の限られた時間内で作 業を終了させることが至上命題であった。そのため,さ まざまな不測の事態を想定して，あらゆる対策を実施し た。主な対策は以下のとおりである。

（1）機械・電気設備の故障や異常への対策

(1)手鎖が 2 か所あるチェーンブロックを使用し, 手鎖 が噛んでも，もう一方の手鎖で操作可能とした。

(2)クレーンが故障した場合でも，隣接したクレーンで 撤去が可能な能力を選定した。

(3)センターホールジャッキ, 油圧ホース, 電動油圧ポ ンプユニットなどの打上・降下設備は予備品を必要 な箇所に配置した。また，予備品の交換試験を実施 して所要時間を把握した。

(4)照明設備はキュービクル (受電設備) と発電機の 2 系統に分け，停電時でも作業場の照明が一斉に消え ることがないようにした。

(5)予備電源用の発電機を用意し, 停電時にも直ちに切 替えられるようにした。

（2）試験施工による作業習熟および所要時間把握 (1)七ンターホールジャッキの模擬装置を作製し, 実際 にゲビンデ棒の挿入・設置方法やセンターホール ジャッキの扛上，降下時のナット調整を行い，作業 習熟を図った（写真-7）。

(2)レールの切断は個人の技量に依存するため, 線路切 替当夜に実際に配置される作業員全員の技量試験を して所要時間の把握と作業習熟を行った。

(3)桁扛上区間（A，Cブロック），当夜クレーン撤去 区間（B，D，E ブロック），桁降下区間（F， G，H， I ブロック）の各ブロックに分け，原位置での当夜 作業シミュレーションを合計 6 回実施し, 線路切替 当夜に向けての確認・見直しを行った。

\section{3 線路切替当夜}

切替当日の平成 25 年 3 月 15 日は, 22 時 30 分より集合 して夜礼を実施し, 各班ごとに最終手順確認を行った。

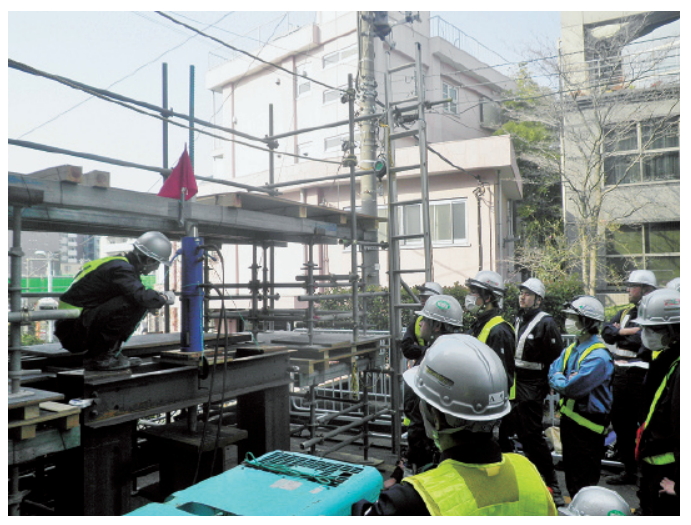

写真-7 センターホールジャッキ模擬装置による試験施工 
表-1 線路切替時間工程表

\begin{tabular}{|c|c|c|c|c|c|c|c|c|c|}
\hline \multicolumn{2}{|c|}{ 工種 時間 } & 22 & 23 & 24 & 1 & 2 & 3 & 4 & 5 \\
\hline \multicolumn{10}{|l|}{ 準備工 } \\
\hline 一部撤去区間 & A ブロック & & & & E & & & & \\
\hline クレーン撤去区間 & B ブロック & & & & = & ש & & & \\
\hline 桁扛上区間 & C ブロック & & & & e & & ש & & \\
\hline クレーン撤去区間 & $\mathrm{D}, \mathrm{E}$ ブロック & & & & E & & 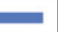 & & \\
\hline 桁降下区間 & $\begin{array}{l}\mathrm{F}, \mathrm{G}, \mathrm{H}, \mathrm{I} \\
\text { ブロック }\end{array}$ & & & & & & & & \\
\hline 軌道工事 & J ブロック他 & & & & & & & & \\
\hline \multicolumn{10}{|l|}{ 電気工事 } \\
\hline & & \multicolumn{3}{|c|}{ 集合 22:30 } & \multicolumn{5}{|c|}{ 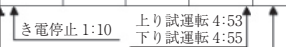 } \\
\hline
\end{tabular}

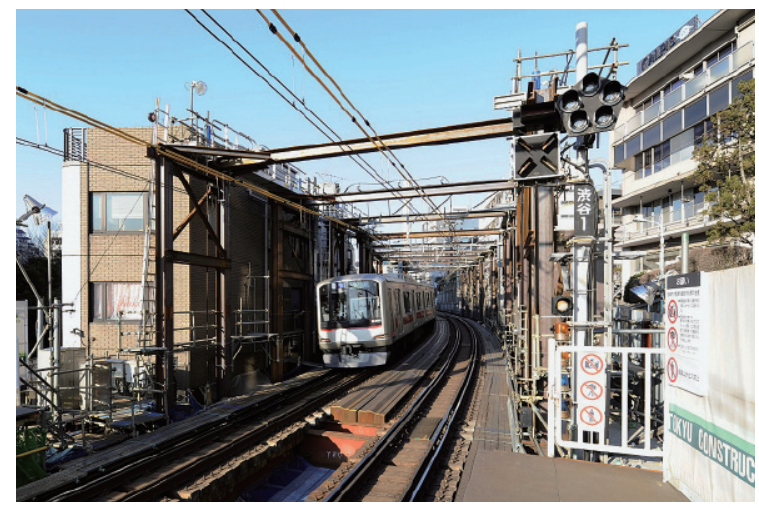

写真-8 切 替 前

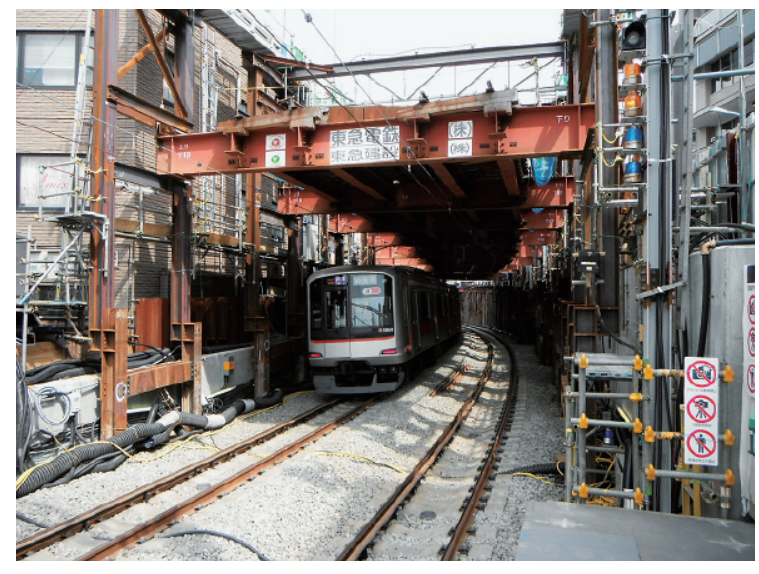

写真-9 切 替 直 後

24 時から現地に移動開始し, 総勢約 1200 人の工事関 係者が作業開始の合図に備えた。

1 時 01 分の区間線路閉鎖確認後, レール破線·切断,

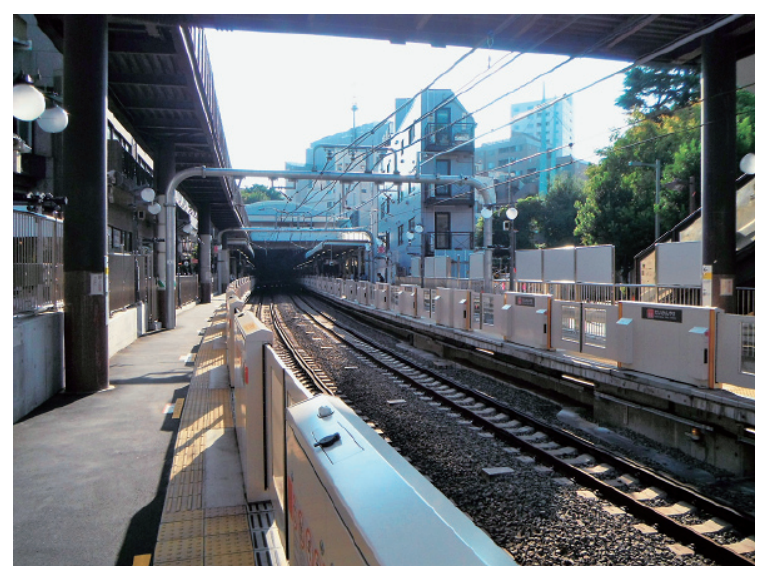

写真-10 地下化工事完了

工事桁固定ボルト撤去を開始した。

各ブロックの切替工事は表-1 に示す時間工程のとお り進行し，点検を含めた全作業終了後，線路閉鎖を解除 し, 試運転列車を上下線各 1 本ずつ走行させて最終確認 を行った。

そして, 予定通り始発の営業列車を向え, 無事に切替 工事が完了した（写真-8，写真-9）。

\section{5. 残躯体構築工事}

線路切替後, 扛上・降下設備等が支障するなど事前に 構築できなかった残りの本設躯体を構築して地下化工事 が完成した（写真-10）。

\section{6.おわりに}

本工事は平成 17 年に着手し，様々な技術的課題にも 直面したが，関係する皆様のご指導，ご協力のもと，前 述のとおり平成 25 年 3 月 15 日に無事に地下線への切替 を終えることができ，本設工事も平成 27 年 3 月に竣工 した。この場をお借りし，お礼を申し上げたい。

これによって東京圈に新たな鉄道ネットワークが形成 されたとともに，東横線は昭和 2 年に施工され約 86 年 経過した高架橋から新設地下トンネルへと切替えられ構 造物が更新された。

既存のインフラ構造物が老朽化するなか, 今後も限ら れた用地内において構造物を供用しながらリニューアル する方法が求められると考えるが，本稿が少しでも参考 になれば幸いである。 